\title{
CONNECTING REGULATIONS AND COMPETITION LAW: A SWISS PERSPECTIVE ON LIBERALIZATION
}

\author{
CHRISTIAN BOVET* AND PHILIPPE GUGLER**
}

\section{INTRODUCTION}

It is debated whether it is possible to liberalize markets successfully by means of introducing unrestrained competition only, or whether it is necessary to have regulators to supervise the opening of markets in adversarial administrative proceedings. Presenting these as the only options, however, oversimplifies the issues involved. That simple opposition suggests that sectoral authorities-which are federal regulatory agencies having jurisdiction over a particular industry-and competition authorities-which are federal agencies with broad jurisdiction over all industries limited to the issue of fostering competition-are antagonistic and that an unrestrained market might, on its own, resolve the problems of liberalization. This view, however, ignores the fact that competition authorities can and do intervene in the market to prevent anti-competitive behaviors such as unlawful agreements and abuse of a dominant market position. Although it is true that regulators often must consider issues related to competition, it is also important to have persons with specialized knowledge of the regulated industries working for these authorities, as well as people qualified for activities specific to the regulator's job, such as the granting of licenses.

When liberalizing its telecommunications industry-the only former public sector industry that is fully liberalized-Switzerland created a special administrative commission to oversee competition and introduced market regulations designed to protect effective competition. A modus vivendi has been established between the regulative and competitive authorities, with close cooperation on certain issues required by law. Measures aimed at liberalizing the electricity sector are also under way. This article is a description of the problems and solutions found in Switzerland. Part II begins with a description of the factual background. Part III discusses present or proposed regulations for the

Copyright $@ 2001$ by Christian Bovet and Philippe Gugler

This article is also available at http://www.law.duke.edu/journals/63LCPBovet.

* Professor of Law, University of Geneva, Switzerland; member of the Swiss Federal Communications Commission ("ComCom").

The opinions expressed in this article are personal and do not bind the Commission in any way.

** Lecturer, International Institute of Management in Telecommunications ("IIMT"), University of Fribourg, Switzerland; Vice-Director, Secretariat of the Swiss Federal Competition Commission.

The opinions expressed in this article are personal and do not bind the Commission in any way. 
telecommunications and electricity industries. Part IV concludes with a discussion of national competition law.

\section{II}

FACTUAL BACKGROUND

\section{A. Terminology}

In recent years, the privatization phenomenon has expanded in industrialized countries. In the process, the term "privatization" has taken on several meanings. ${ }^{1}$ In everyday use, privatization often is simply equated with market liberalization. However, the terms are not synonymous. "Privatization" in its narrowest sense refers to the opening of the capital of a state-owned industry to private investors. ${ }^{2}$ France and England have seen several waves of this sort of privatization as control of their governments has swung from the right to the left and back again. Typically, right-leaning governments move to privatize industrial companies involved in energy production, banks, insurance companies, and national railways. Market liberalization, on the other hand, refers to ending a state monopoly in an economic sector while usually maintaining government regulation of the industry. Once liberalization is realized, consumers have a choice among several operators.

Strictly speaking, then, privatization is distinct from market liberalization. However, privatization of some portion of an industry previously under the complete control of the state often entails market liberalization, as demonstrated by the recent liberalization of the telecommunications market in Switzerland, which is discussed below. ${ }^{3}$ There has not yet been any real, stricto sensu, privatization in Switzerland; the Swiss Confederation still controls the majority of the share capital of the Swiss Telecommunications Company ("Swisscom"), which was "privatized" in 1998. ${ }^{4}$ If this article dealt with privatization in the narrower sense, it would conclude right here.

In addition to market liberalization, a third form of privatization, in the broad sense, consists of changing the structure of public services. In this sort of privatization, no true liberalization takes place. Instead, the state retains ownership of the public service, but the government modifies its organization and

1. See Tobias Jaag, Dezentralisierung und Privatisierung öffentlicher Aufgaben: Formen, Voraussetzungen und Rahmenbedingungen, in DEZENTRALISIERUNG UND PRIVATISIERUNG ÖFFENTLICHER AUFGABEN 23 (Tobias Jaag ed., 2000); Blaise Knapp, Quelles limites constitutionnelles aux privatisations?, REVUE SUISSE DE DROIT DES AFFAIRES 1 (Special issue 1999).

2. One of the first significant publications on the subject is RECHTLICHE PROBLEME DER PRIVATISIERUNG, BERNER TAGE FUR DIE JURISTISCHE PRAXIS-BTJP 1997 (Wolfgang Wiegand ed., 1998). See also the detailed bibliography in Jaag, supra note 1 . For a recent and complete presentation of aspects pertaining to the status of civil servants, see FONCTION PUBLIQUE: VERS UNE PRIVATISATION? (Gabriel Aubert et al. eds., 2000).

3. See Federal Law on Telecommunications of April 30, 1997, Recueil systématique du droit fédéral [RS] 784.10 (Switz.) and related regulations, RS 784.101-784.491.

4. See Decree of Oct. 6, 1997, Recueil officiel des lois et ordonnances de la Confédération suisse [RO] 19972206 (Switz.). 
management. Typically, the legislature will pass a special law granting independence to the persons and assets generating the activity in question, which becomes part of a separate body with its own capital. The new entity takes the form of a private law company, or a so-called "public establishment." All rights and obligations relating to the activity are transferred to the new entity. The most significant example of this type of privatization in Switzerland is the restructuring of the Swiss Railways. ${ }^{5}$ Less far-reaching, perhaps, but equally interesting, is the privatization of the Swiss Federal Institute for Intellectual Property, which transferred all activities of the federal office managing patents, trademarks, and copyrights to a new independent entity. ${ }^{6}$ Such reorganizations are known in Switzerland and elsewhere in Europe as the "new public management."

\section{B. General Economic Background}

State monopolies generally involve public services and the use of public property (domaine public). The three main privatization projects in Switzerland-telecommunications, electricity, and railways-all involve these public features. Before the process of privatization began, all were natural monopolies. They were also legal monopolies because they were institutionalized by law and, in some cases, by the federal constitution. ${ }^{8}$

Liberalization is most mature in the telecommunications industry. Some telecommunications resources, such as radio frequencies and satellite orbits, are scarce because it is not feasible for all service providers to have parallel or simultaneous use of them. Telephone numbers and internet domain names are also scarce because they are determined by a finite number of characters, further constrained by our limited ability to memorize the characters.

Other telecommunication resources are unlimited in theory, but for technical or economic reasons, several market participants need access to them. The usual network of copper or optic fiber cables serving ordinary communications could be duplicated by each market participant. Each operator could install its own parallel cable network on the same property. It would not be economically feasible to do so, however, because there are 300 such operators in Switzerland today, after only two and a half years of liberalization. ' It is more economical for these operators to use the existing network of the former monopolist. Beyond the laying of cable, new operators would also have to undertake the cost

5. See Federal Law on Federal Railways of March 20, 1998, RS 742.31 (Switz.).

6. See Federal Law on the Status and Tasks of the Federal Institute for Intellectual Property of March 24, 1995, RS 172.010.31 (Switz.).

7. This is a multiform concept. See PhilipPe Mastronardi \& Kuno Schedler, New PubliC MANAGEMENT IN STAAT UND RECHT, EIN DISKURS (1998).

8. See CONSTITUTION FÉDÉRALE [CST.] arts. 24-bis, 36 (1874) (Switz.). These monopolies are no longer institutionalized in the Swiss Federal Constitution. See CsT. arts. 91, 92 (1999) (effective Jan. 1, 2000), RS 101.

9. See list of service providers (visited Nov. 29, 2000) <http://www.bakom.ch/Service_Provider_ Liste/welcome_f.html>. 
of acquiring a web of real estate rights parallel to the one acquired over the years by the former monopolist.

Liberalization in the telecommunications industry has resulted in the creation of two main markets, one in network access (interconnection), and another in all other telecommunications services. ${ }^{10}$ Operators will have to share some of their telecommunications installations (collocation) and, in some situations, coordinate the use of public property. These situations arise not only when it comes to scarce resources, but also for other resources. ${ }^{11}$ The principles developed in liberalizing the telecommunications industry inspired lawmakers who subsequently turned to liberalize the electricity industry. ${ }^{12}$

III

\section{REGULATORY FRAMEWORK}

\section{A. Telecommunications}

This section introduces the general regulatory framework for the liberalization of the telecommunications market established by the World Trade Organization ("WTO") $)^{13}$ and Switzerland's full implementation of the WTO rules in its own national regulations. ${ }^{14}$

The WTO is the successor of the General Agreement on Tariffs and Trade of 1947 ("GATT 47") " $^{15}$ and is now the main international body regulating the public law aspects of international trade. The WTO superseded the position of its predecessor by acquiring legal status as an international organization and by increasing the number and representation of member states. In addition, its regulations are far more specific and precise, making them easier to comply with and to enforce.

Four main agreements complete the Agreement Establishing the World Trade Organization signed at Marrakech, Morocco, in December 1994: (1) General Agreement on Tariffs and Trade 1994" ("GATT 94"); (2) General Agreement on Trade in Services" ("GATS"); (3) Agreement on Trade-Related

10. See Commission Notice on the Application of the Competition Rules to Access Agreements in the Telecommunications Sector, 1998 O.J. (C 265) 2.

11. See discussion infra Section III.A.

12. See discussion infra Section III.B.

13. See Marrakesh Agreement Establishing the World Trade Organization, Dec. 15, 1993, 33 I.L.M. 1 (1994) [hereinafter WTO Agreement].

14. See Federal Law on Telecommunications of April 30, 1997, RS 784 (Switz.).

15. See General Agreement on Tariffs and Trade, Oct. 30, 1947, 61 Stat. A-11, T.I.A.S. 1700, 55 U.N.T.S. 194 [hereinafter GATT 47].

16. See General Agreement on Tariffs and Trade 1994, Apr. 15, 1994, WTO Agreement, supra note 13, Annex 1A, LEGAL InSTRUMENTS-RESUlTS OF THE URUGUAY ROUND [hereinafter LEGAL INSTRUMENTS] vol. 21; 33 I.L.M 28 (1994) [hereinafter GATT 94].

17. See General Agreement on Trade in Services, Apr. 15, 1994, WTO Agreement, supra note 13, Annex 1B, art. XV, LEGAL InSTRUMENTS, supra note 16, vol. 31; 33 I.L.M. 51 (1994) [hereinafter GATS]. 
Aspects of Intellectual Property Protection" ("TRIPS"); and (4) Understanding on the Rules and Procedures Governing the Settlement of Disputes ("DSU"). The Agreement on Technical Barriers to Trade, which plays a very significant role in the opening of markets, is also relevant to the telecommunications industry. ${ }^{20}$ Its provisions aim at ensuring that technical regulations (1) treat like products the same whether they are of domestic origin or are imported from any country that is a party to the agreement and (2) are not written, adopted, or applied with the intention or effect of creating unnecessary obstacles to international trade. ${ }^{21}$ The principles embodied in these provisions are implemented in national and multinational regulations governing telecommunications equipment and installations. ${ }^{22}$ Because the parties could not reach a full agreement on access to the telecommunications market in 1994, they decided to begin by defining the basis for negotiations in an Annex to GATS. ${ }^{23}$ These discussions resulted in the Fourth Protocol to the GATS of April 1997..$^{24}$

To understand that document, it is necessary first to understand the main provisions of GATS. The provisions of both the WTO agreements and their predecessor, GATT, recognize two categories of commitments: (1) the general commitment that may not be undermined or modified by the parties to recognition of most-favored nation status ("MFN status") ${ }^{25}$ and (2) the specific commitments of the nations that are parties to the agreement. General commitments apply horizontally to all sectors and to all members, whereas specific commitments apply only to specific sectors in specific member nations. These latter commitments vary from country to country. The terms, limitations, and conditions to which each nation agreed are presented in individual schedules of commitments. ${ }^{26}$ The extent of a member state's obligations and the treatment of foreign service suppliers may be determined by referring to these documents.

18. See Agreement on Trade-Related Aspects of Intellectual Property Protection, Apr. 15, 1994, WTO Agreement, supra note 13, Annex VII, art. 65.2, LEGAL INSTRUMENTS, supra note 16, vol. 31; 33 I.L.M. 81 (1994) [hereinafter TRIPS].

19. See Understanding on Rules and Procedures Governing the Settlement of Disputes, Apr. 15, 1994, WTO Agreement, supra note 13, Annex II, art. 4, LEGAL INSTRUMENTS, supra note 16, vol. 31; 33 I.L.M. 112 (1994) [hereinafter DSU].

20. See Agreement on Technical Barriers to Trade, Apr. 15, 1994, WTO Agreement, supra note 13, Annex 1A, LEgAL InSTRUMENTS, supra note 16, vol. 31; 33 I.L.M. 1125 (1994) [hereinafter TBT Agreement].

21. See id. art. 2.

22. See, e.g., Federal Law on the Elimination of Technical Obstacles to Trade of Oct. 6, 1995, RS 946.51 (Switz.).

23. See GATS, supra note 17, Annex on Telecommunications, LEgAl TEXTS-Results of THE Uruguay Round of Multilateral Trade Negotiations [hereinafter Legal Texts] 359, II 3(b)-(c) (GATT Secretariat 1994), 33 I.L.M. 1192 (1994) [hereinafter GATS, Annex on Telecommunications].

24. See different nations' schedules of specific commitments (visited Nov. 30, 2000) <http://www. wto.org/wto/ddf/ep/public.html> [hereinafter Schedules of Commitments].

25. See GATS, supra note 17, art. II(1) ("With respect to any measure covered by this Agreement, each Member shall accord immediately and unconditionally to services and service suppliers of any other Member treatment no less favorable than that it accords to like services and service suppliers of any other country.").

26. See Schedules of Commitments, supra note 24. 
Several GATS provisions aim at opening markets, by measures such as (1) setting reasonable standards regarding domestic regulations $;^{27}$ (2) requiring recognition of foreign authorizations, licenses, or other certifications of service suppliers $;^{28}(3)$ ensuring market access ${ }^{29}$ and (4) specifying national treatment. ${ }^{30}$ Additionally, GATS contains two provisions applying to the specific commitments that seek to protect competition. Article VIII of GATS is drafted in rather strong terms to curtail abuses of monopolies and to prevent exclusive service suppliers. ${ }^{31}$ On the other hand, Article IX simply provides that "[m]embers recognize that certain business practices of service suppliers, other than those falling under Article VIII, may restrain competition and thereby restrict trade in services." ${ }^{32}$ Obviously, this provision leaves a great deal of discretion to the member nations as to the definition of these restraints on competition, the regimes applying to them, and the measures available to a nation's authorities to oppose them. ${ }^{33}$ Article IX of GATS states the principle of positive comity. ${ }^{34}$

The results of the WTO negotiations on basic telecommunications are contained in the Fourth Protocol, which includes the commitments of sixty-nine governments as specified in fifty-five schedules. ${ }^{35}$ All industrialized countries participated in the deal, and more than forty developing countries also took part. $^{36}$ The markets of the participants accounted for eighty-two per cent of global telecommunication revenues. ${ }^{37}$ The participants in the negotiations succeeded in elaborating a set of principles covering matters such as competition safeguards, interconnection guarantees, transparency in licensing processes, and

27. See GATS, supra note 17 , art. VI.

28. See id. art. VII.

29. See id. art. XVI.

30. See id. art. XVII.

31. See id. art. VIII (providing that "each Member shall ensure that any monopoly supplier of a service in its territory does not, in the supply of the monopoly service in the relevant market, act in a manner inconsistent with that Member's obligations under Article II and specific commitments") (emphasis added).

32. Id. art. IX (emphasis added).

33. For a discussion of the efforts to set up an international antitrust code within the framework of the WTO, see TOWARDS WTO COMPETITION RULES: KEY ISSUES AND COMMENTS ON THE WTO REPORT (1998) ON TRADE AND COMPETITION (Roger Zäch ed., 1999).

34. It provides that:

Each Member shall, at the request of any other Member, enter into consultations with a view to eliminating practices referred to in paragraph 1 . The Member addressed shall accord full and sympathetic consideration to such a request and shall cooperate through the supply of publicly available non-confidential information of relevance to the matter in question. The Member addressed shall also provide other information available to the requesting Member, subject to its domestic law and to the conclusion of satisfactory agreement concerning the safeguarding of its confidentiality by the requesting Member.

GATS, supra note 17, art. IX.

35. See Fourth Protocol to GATS, supra note 17, 36 I.L.M. 354 (1997) [hereinafter Fourth Protocol].

36. See id.

37. See Council for Trade in Services, Telecommunication Services: Background Note by the Secretariat, Dec. 8, 1998, at 2 (visited Nov. 29, 2000) <http://www.wto.org/wto/english/tratop_e/serv_e/ w74.doc>. 
the independence of regulators. ${ }^{38}$ In substance, the Fourth Protocol aims at making domestic telecommunication regulations market-oriented and curtailing the discretion of regulatory agencies. ${ }^{39}$ Indeed, if discretionary public interest regulations were to discriminate against foreign suppliers, these regulations would violate the WTO agreements. ${ }^{40}$

The contents of the Fourth Protocol were previously described in a negotiated text called the "Reference Paper." ${ }^{41}$ The signatories of the Fourth Protocol also agreed to use this document as a tool to decide which regulatory disciplines to undertake as additional commitments, as is evident from a comparison of the Reference Paper with the various schedules of specific commitments. ${ }^{42}$

Each nation's schedule of commitments contains a commitment to maintain specific measures to prevent suppliers from unilaterally or collectively engaging in anti-competitive practices. ${ }^{43}$ Such anti-competitive practices include engaging in cross-subsidization, using information obtained from competitors for anticompetitive results, and failing to make technical information about essential facilities and commercially relevant information needed for the provision of services available to other service suppliers on a timely basis. ${ }^{44}$ The Fourth Protocol defines a "major supplier" as one with the power "materially [to] affect the terms of participation," either due to its control over essential facilities or its market position. ${ }^{45}$ This definition is important to all nations applying interconnection, because it guarantees that they must provide interconnection under the following conditions:

[1] under non-discriminatory terms, conditions (including technical standards and specifications) and rates and of a quality no less favourable than that provided for its own like services or for like services of non-affiliated service suppliers of for its subsidiaries of other affiliates;

[2] in a timely fashion, on terms, conditions (including technical standards and specifications) and cost-oriented rates that are transparent, reasonable, having regard to economic feasibility, and sufficiently unbundled so that the supplier need not pay for network components of facilities that it does not require for the service to be provided; and

38. See General Obligations and Disciplines, GATS, supra note 17 (visited Nov. 29, 2000) $<$ http://www.wto.org/english/tratop_e/serv_e/2-obdis.htm>.

39. See id.

40. See Toshiaki Takigawa, The Impact of the WTO Telecommunications Agreement on U.S. and Japanese Telecommunications Regulations, 32(6) J. WORLD TRADE 33 (1998).

41. See Negotiating Group on Telecommunications, Reference Paper (Apr. 24, 1996) (visited Nov. 29, 2000) <http://www.wto.org/english/tratop_e/servte_e/tel23_e.htm> [hereinafter Reference Paper].

42. Compare Reference Paper, supra note 41, with Schedules of Commitments, supra note 24.

43. See Schedules of Commitments, supra note 24.

44. See id.

45. GATS, supra note 17, pts. IV, VI; see also ORGANISATION FOR ECON. COOP. AND DEV., IMPLICATION OF THE WTO AGREEMENT ON BASIC TELECOMMUNICATIONS, JOINT GROUP ON TRADE AND COMPETITION (1999). 
[3] upon request, at points in addition to the network termination points offered to the majority of users, subject to charges that reflect the cost of construction of necessary additional facilities. ${ }^{46}$

All WTO member nations are bound by and benefit from these negotiated terms because of their MFN status. It was possible, however, for the participants to file an MFN exemption on measures affecting trade in basic telecommunications services. Nine governments submitted exemption lists to be annexed to the Fourth Protocol. ${ }^{47}$ For example, the exemption filed by the United States relates to one-way satellite transmissions to direct home broadcasting and direct broadcasting by satellite television services and digital audio services. $^{48}$

The Swiss schedule of specific commitments covers telephone, packetswitched data transmission, circuit-switched data transmission, and telex, telegraph, facsimile, and private leased circuit services. ${ }^{49}$ Switzerland committed to maintaining no limitation on market access and to national treatment of crossborder trade, consumption abroad, and commercial presence. ${ }^{50}$ The United States submitted commitments related mainly to the same services ${ }^{51}$ though it also listed some limitations on market access. ${ }^{52}$ For instance, the United States reserved Comsat's exclusive rights to links with Intelsat and Inmarsat. ${ }^{53}$

India, also a potentially significant telecommunications market, submitted a rather limited schedule of commitments. ${ }^{54}$ It made no commitment for crossborder trade or for consumption abroad. ${ }^{55}$ It also made no commitment on national treatment and introduced several limitations on market access. ${ }^{56}$ Finally, India submitted two MFN exemptions related to international telecommunications services. ${ }^{57}$

Although the Fourth Protocol is limited to trade in services, it might have implications for trade in goods and for more general multilateral rulemaking on competition. $^{58}$ Indeed, it is based on the GATS commitments to MFN status and national treatment linked to schedules of commitments, as well as on spe-

46. Switzerland's Schedule of Specific Commitments $§ 2.2$, Schedules of Commitments, supra note 24 [hereinafter Switzerland's Schedule].

47. See Schedules of Commitments, supra note 24 (setting forth schedules of specific commitments for Antigua and Barbuda, Argentina, Bangladesh, Brazil, India, Pakistan, Sri Lanka, Turkey, and the United States).

48. See United States's Schedule of Specific Commitments, Schedules of Commitments, supra note 24 [hereinafter United States's Schedule].

49. See Switzerland's Schedule, supra note 46.

50. See id.

51. See id.; United States's Schedule, supra note 48.

52. See id.

53. See id.

54. See id.; India's Schedule of Specific Commitments, Schedules of Commitments, supra note 24.

55. See id.

56. See id.

57. See id.

58. See OrganisAtion FOR ECON. COOP. AND DEV., supra note 45. 
cific provisions imposing transparency guarantees and measures against abuses of dominance by monopoly suppliers.

One of the remaining unresolved questions about GATS and its accessory agreements is whether they have direct effect in the legal systems of the member states. Can they be invoked as self-applicable sources of law in domestic courts without having first been incorporated into domestic legal systems? Decisions of the European Community Court of Justice regarding GATT 47 indicate that the answer to this question is no. ${ }^{59}$ In International Fruit v. Produktschap voor Groenten en Fruit, the court held that these rules had no direct domestic effect because of their high level of flexibility. ${ }^{60}$ This position was confirmed twenty-two years later in Germany v. Council, where the court stated that these provisions were not without conditions. ${ }^{61}$ The court may apply a different analysis under GATT 94 and its related regulations, as evidenced in its 2000 Bureau Européen des Unions des Consommateurs ("BEUC") decision, where the European Community Court of First Instance stated:

[I]n [International Fruit], the Court of Justice ruled that the provisions of the General Agreement on Tariffs and Trade [of 1947] had the effect of binding the Community. The same conclusion must be reached both in the case of GATT $1994 \ldots$ and in the case of the 1994 Anti-Dumping Code ... .

Secondly, it is worth emphasising that the third point in the recital in the preamble to the Basic Regulation states that the latter was adopted "to amend the Community rules in the light of" the new Agreements concluded at the end of the multilateral trade negotiations of the Uruguay Round (1986-1994), including the Antidumping Code. Furthermore, the fifth recital in the preamble to that regulation states that the Antidumping Code "contains new and detailed rules," relating in particular to the calculation of dumping, procedures for initiating and pursuing an investigation, including the establishment and treatment of the facts, the imposition of provisional measures, the imposition and collection of anti-dumping duties, the duration and review of antidumping measures and the public disclosure of information relating to anti-dumping investigations, and that "in view of the extent of the changes and to ensure a proper and transparent application of the new rules, the language of the new agreements should be brought into Community legislation as far as possible."

67. It follows that the Commission is right to interpret the Basic Regulation in the light of the Antidumping Code. ${ }^{62}$

The European Community Court of Justice took a similar approach in its 1998 Hermès International decision, where it stated:

[S]ince the Community is a party to the TRIPS Agreement and since that agreement applies to the Community trade mark, the courts referred to in Article 99 of Regulation No 40/94, when called upon to apply national rules with a view to ordering provi-

59. See, e.g., Cases 21-24/72, International Fruit Co. v. Produktschap voor Groenten en Fruit, 1972

E.C.R. 1219; Case C-280/93, Germany v. Council, 1994 E.C.R. I-4973.

60. See International Fruit, 1972 E.C.R. II 21.

61. See Germany v. Council, 1994 E.C.R. I-4973 II 9.

62. Case T-256/97 Bureau Européen des Unions des Consommateurs (BEUC) v. Commission of the European Communities, 2000 E.C.R. __, (visited Dec. 4, 2000) <http://curia.eu.int/jurisp/cgibin/form.pl?lang $=$ en $\&$ Submit $=$ Submit $\&$ docrequire $=$ alldocs $\&$ numaff $=t-256 \% 2 \mathrm{~F} 97 \&$ datefs $=\&$ datefe $=\&$ nomusuel $=\&$ domaine $=\& \operatorname{mots}=\& \operatorname{resmax}=100>$. 
sional measures for the protection of rights arising under a Community trade mark, are required to do so, as far as possible....

1. National Law in General. The Swiss telecommunications market was fully liberalized on January 1, 1998. ${ }^{64}$ Consumers may now freely choose their telecommunication services provider or providers. Market supervision has been entrusted to the Swiss Federal Communications Commission ("ComCom"), ${ }^{65}$ an authority fully independent from the government, which acts in cooperation with the Federal Communication Office ("OFCOM"). ${ }^{6}$

The Swiss Federal Law on Telecommunications of April 30, 1997 ("LTC") sets the general rules governing the liberalization of the Swiss telecommunications market. ${ }^{67}$ The Swiss Federal Council (that is, the national government), the competent federal department - in this case the Federal Department of Environment, Transport, Energy and Communications ("DETEC")—ComCom, and OFCOM adopted several ordinances and regulations implementing the LTC $^{68}$ In addition, the Swiss Parliament passed the Federal Law on the Organization of the Telecommunication Company of April 30, 1997, which defined the status of the former monopolist after the liberalization. ${ }^{69}$ The following sections focus on the main instruments used in granting and accelerating market access-the LTC and the Ordinance on Telecommunication Services ("OTS").

2. Instruments of Liberalization. Interconnection, which has been the main instrument of liberalization, is the linking of telecommunication transportation networks among suppliers that allows the users of one supplier to communicate with users of another network and to access services provided by another supplier. $^{71}$ Regulations impose the duty to participate in interconnection on major suppliers. Swiss law designates as major suppliers those operators

63. Case C-53/96, Hermès Int'l v. FHT Marketing Choice BV, 1998 E.C.R. I-3603, II 28.

64. See Decree of Oct. 6, 1997, RO 19972206.

65. See ComCom's website (visited Sept. 10, 2000) <http://www.fedcomcom.ch>.

66. See OFCOM's website (visited Sept. 10, 2000) <http://www.bakom.ch/eng/>.

67. See Swiss Federal Law on Telecommunications of April 30, 1997, RS 784.10 [hereinafter LTC].

68. See Swiss Federal Council's Ordinance on Telecommunication Services of Oct. 6, 1997, RS 784.101 (Switz.) [hereinafter OTS].

69. See RS 784.11. For a discussion of the transfer of assets beyond privatization, see Rolf $\mathrm{H}$. Weber, Fragen der Vermogensübertragung bei der Überführung öffentlicher Aufgaben auf verwaltungsexterne Rechtsträgerin DEZENTRALISIERUNG UND PRIVATISIERUNG ÖFFENTLICHER AUFGABEN 67 (Tobias Jaag ed., 2000).

70. See OTS, supra note 68 .

71. With minor changes, the above definition is based on the essential components of the WTO definition. Each multilateral and national regulation contains its own definition of interconnection. Although the European definition is rather sophisticated, it describes exactly the same concept as Section 2 of the GATS Fourth Protocol. See Fourth Protocol, supra note 35; LTC, supra note 67, art. 3(e); Commission Directive 97/33/EC of the European Parliament and of the Council of June 30, 1997, on Interconnection in Telecommunications with Regard to Ensuring Universal Service and Interoperability through Application of the Principles of Open Network Provision ("ONP"), art. 2(1)(a), 1997 O.J. (L 199) 32 [hereinafter Directive 97/33/EC]. 
holding a dominant position under competition law. ${ }^{72}$ The implementation of these obligations is governed by two principles. First, major suppliers must grant other suppliers interconnection under non-discriminatory terms, conditions, and rates. The former monopolist cannot treat one supplier better than any others. The standards of the interconnection provider applied within the group will serve as a basis for the assessment of the quality of the interconnection service. As a result, service to other suppliers must be comparable to that provided to the major supplier's subsidiaries and affiliates. Interconnection rates imposed upon third parties must not be less favorable than those applied internally to member entities of the interconnection provider's group. ${ }^{73}$ Information and technical means must be shared under the same terms and conditions and with the same level of quality. ${ }^{74}$

Second, a reasonable amount of transparency must be maintained. Information pertaining to interconnection agreements and to costs must remain publicly available. The website of OFCOM, for example, explicitly mentions the interconnection agreements each provider entered with Swisscom, the former monopolist. ${ }^{75}$ Any market participant—or even any web user-can know which provider is receiving interconnection services. Anyone who establishes a valid interest-beyond mere curiosity-is entitled to examine the contracts themselves, absent an overriding private or public interest in protecting the information. $^{76}$

To facilitate the opening of the telecommunications market, interconnection rates must be tied to costs. Beyond the economic need, this requirement is based on the policy rationale that, because the former monopolist was able to build its network partly at the expense of the community, it should redistribute this competitive advantage to other operators; otherwise, the monopolist will realize a windfall. Calculating the costs of interconnection is delicate work, however, because there are costs directly related to the interconnection of the network, as well as costs arising from its establishment, maintenance, and renewal. ${ }^{77}$ The law also seeks to impart to the interconnection provider a reasonable return on its investment. If the provider cannot determine its costs, the

72. See LTC, supra note 67, art. 11. This concept is similar to (1) the provisions of Directive 97/33/EC, supra note 71, arts. 4(2)-(3), which use the concept of "significant market power" and (2) the main hypothesis defined by Directive 97/33/EC, annex II, which refers to operators controlling network access in one or several network termination points ("NTPs"). The Swiss and European Union regulations should implement these provisions thanks to the proposed changes relating to the European regulatory framework. See Commission Proposal for a Directive of the European Parliament and of the Council on Access to, and Interconnection of, Electronic Communications Networks and Associated Facilities, $\mathrm{COM}(00) 384$ at 4.

73. See Schedules of Commitments, supra note 24.

74. See id.

75. See Service Providers for Switzerland (visited Dec. 2, 2000) <http://www.bakom.ch/Service_ Provider_Liste/welcome.html>.

76. See LTC, supra note 67, art. 11(5).

77. See Christian Bovet, Réception du droit public économique étranger en Suisse, 3 SocIÉTÉ SUISSE DES JURISTES: RAPPORTS ET COMMUNICATIONS 277, 291 (2000) (comparing the regimes applied in Switzerland and the European Union). 
regulator will likely perform a comparative study. ${ }^{78}$ These procedures will prove useful in other portions of the telecommunications industry as well, particularly in the case of collocation. ${ }^{79}$ The law states:

The Federal Office [OFCOM] may, for reasons of public interest, in particular due to technical difficulties, developmental needs or protection of the countryside, the national heritage, or wildlife, require the holder of a license for telecommunication services to accord to a third party, in return for appropriate compensation, the right to make joint use of its installations and transmitters, provided they have sufficient capacity. The provisions on interconnection (Art. 11) shall apply mutatis mutandis. ${ }^{80}$

In substance, the regime for which this rule provides may be presented as follows: First, the obligation exclusively targets license holders. Although transmitters or other equipment are sometimes installed on public land, the state is not directly concerned with this regime. Second, the decision is made by OFCOM within an ordinary administrative procedure; the interested parties are heard by the federal authority. Third, a license holder using the installations of another must properly indemnify the latter for this collocation. ${ }^{81}$ Article 28 of OTS merely states that "total costs" must be shared in adequate proportions between the suppliers involved in the project. $^{82}$ Although there is no practice in this field yet, one could argue that some additional indications may be found in OTS provisions dealing with interconnection, and that the rather-developed accounting regime applied today in relation to interconnection could also govern collocation to a broad extent in the future.

In early 2000, the Swiss Federal Council adopted an ordinance on nonionizing radiation. ${ }^{83}$ The aim of the regulation is to protect the environment and, in particular, human beings, against the possibly negative effects of this physical phenomenon. This ordinance might actually clash with the practice of collocation, which in great part pursues the same objective. For example, the Ordinance on Radiation provides that, in order to calculate the relevant rates,

78. See Directive 97/33/EC, supra note 71, art. 7(2) (putting the burden of proof regarding the establishment of real costs on the interconnection provider).

79. See Fifth Report on the Implementation of the Telecommunications Regulatory Package, $\operatorname{COM}(99) 537$ final, at annex 3.25 (visited Nov. 30, 2000) <http://europa.eu.int/comm/information society/policy/telecom/5threport/index_en.htm $>$.

80. LTC, supra note 67, art. 36(2), translated in 1 ANDRÁs A. GUROVITS, ET AL., DAS SCHWEIZERISCHE TELEKOMMUNIKATIONSRECHT LE DROIT DES TÉLÉCOMMUNICATIONS SUISSE 142 (1998) (emphasis added). The extent of this reference to interconnection rules is difficult to determine. For instance, ComCom decides on the interconnection rate, while OFCOM determines the amount of the indemnification in case of collocation. Article 11 of LTC defines a three-stage procedure with respect to interconnection: (1) the parties must first try to reach an agreement on the interconnection rate; (2) if they fail to do so, then ComCom will make a formal decision on the issue; and (3) this decision may be submitted in an appeal procedure to the Swiss Federal Tribunal. See id. The first two steps may also occur in a collocation procedure, except that the decision will be taken by OFCOM, not ComCom. But appeals against the OFCOM's decision will have to be filed before the Swiss Federal Appeal Commission of the Department of Environment, Transport, Energy and Communications, not the Federal Tribunal. However, this commission's decision may be eventually appealed before the latter court.

81. See LTC, supra note 67, art. 36(2).

82. See OTS, supra note 68 , art. 28.

83. See Ordinance on the Protection against Non-Ionizing Radiation, RS 814.710 (visited Nov. 16, 2000) <http://www.admin.ch/ch/f/rs/c814_710.html > [hereinafter Ordinance on Radiation]. 
one must take into account all the installations that are on the mast. ${ }^{84}$ In fact, this might make it technically difficult to reconcile the objective of Article 36 of LTC - avoiding a "forest of telecommunication masts"-with the radiation protection objective proposed by the ordinance. ${ }^{85}$ In addition, this type of regulation will have essentially a negative impact on the development of the mobile telecommunication networks of new market entrants, because the former monopolist will have already built most of its networks. ${ }^{86}$

The third instrument available to the lawmaker in order to favor the opening of the telecommunication market is the use of land. Indeed, it can institute a flexible regime with respect to rights-of-way-as is the case in Switzerland. ${ }^{87}$ Under Article 35 of LTC:

1 Owners of land in public use (such as roads, footpaths, public squares, waterways, lakes and river banks) are required to allow license holders for telecommunication services to use that land to install and operate lines and public call boxes, provided those installations do not interfere with the public use of the land.

2 License holders for telecommunications services shall show consideration for the use for which the property in question is put and shall bear the cost of restoring it to its original state. They are required to move their lines if the property owner wishes to use the property for a purpose that is incompatible with their presence.

3 The Federal Council shall regulate the detailed rules for implementation, in particular the license holder's duty of co-ordination and the conditions governing the relocation of lines and public call boxes.

4 The authorization procedure shall be simple and rapid. No charge other than a charge to cover costs may be levied for the use of the land, provided that it does not interfere with its public use. ${ }^{88}$

These provisions are supplemented by Articles $25-27$ of OTS. ${ }^{89}$ Regarding the duty of coordination imposed by the LTC on license holders, the ordinance provides that license holders are not bound to comply with that obligation if it would prevent the necessary work from being completed within three months of the day when the authorization was granted. ${ }^{90}$ In addition, telecommunication companies are entitled to seek information from other undertakings regarding future projects that may have an impact on their installations on land in use; the requested undertakings must reply within a mandatory four-week deadline. ${ }^{91}$

The four main features of the regime set up by the LTC with respect to rights-of-way are the following: First, the rights provided for by Article 35 relate exclusively to land in public use. Excluded from the field of application of

84. See id. annex 1, item 62, II 2.

85. LTC, supra note 67, art. 36.

86. See 1998 COMCOM ANN. REP. 14-15 (visited Nov. 30, 2000) <http://www.fedcomcom.ch leng/commission/report.98.pdf>.

87. See Pierre-Yves Gunter, Les infrastructures, in NEUES FERNMELDERECHT, ERSTE ORIENTIERUNG 51 (Rolf H. Weber ed., 1998).

88. LTC, supra note 67 , art. 35.

89. See OTS, supra note 68 , arts. 25-27.

90. See id. art. 25(1).

91. See id. art. 25(2). 
this provision are (1) real estate owned by the state but assigned to private use (so-called "private" or "financial" assets of the state) and (2) real estate owned by individuals or companies. ${ }^{92}$ Second, the beneficiaries of these rights are exclusively telecommunication license holders. Companies registered in another capacity with $\mathrm{OFCOM}^{93}$ cannot make a request based on Article 35 of LTC. $^{94}$ Even companies engaged in related fields of activity (such as electricity or water supply undertakings) do not enjoy this special regime. Third, license holders have the right to obtain, and the authorities have the obligation to grant, the authorization to use streets and roads, for example, for the installation of telecommunication lines. This authorization must be granted within the framework of a simple and rapid procedure. During the parliamentary debates, there was even mention of a maximum one-week period between the filing of the request and the granting of the authorization; such moves sought to accelerate the liberalization of the telecommunication market and the arrival of new providers. Fourth, the granting of the authorization normally is not subject to any indemnification. The cantons and municipalities can require the payment of only an administrative fee. In Geneva, for instance, this fee amounts to 500 Swiss francs. The only exception to this rule is the case where the lines permanently affect the use of the land on which they are installed.

Market access can also be obtained through roaming. Roaming occurs when a mobile telecommunication supplier ensures geographical coverage to another supplier who does not yet have a sufficient network. The characteristic of this system is that the services provided by the first supplier are still billed by the second supplier to its own customers, so that there is no transfer of clients. The latter can continue using its mobile phones in the same manner as before, without any significant change in the technical configuration of its outlets. There is also an "internal" billing between the two suppliers. The supplier lacking coverage has an obvious economic and commercial interest in rapidly improving its geographical coverage, because its provider will endeavor to get as much money as possible from this situation. Roaming is not governed by any specific provision of the LTC or its implementing ordinances. It is a purely contractual arrangement between telecommunication services suppliers, a very common practice at the international level. In fact, it is one of the essential features of mobile telecommunications.

In Switzerland, a roaming agreement was formed between the former monopolist Swisscom and a new market entrant, Orange Communications SA. Another provider complained to ComCom, alleging, among other things, that this system was hurting effective competition among providers. The authority rejected this argument on the basis that the Swiss law had wanted, above all, competition on services rather than on infrastructure, and that the solution set up by the parties was, in any event, a temporary one. In addition, ComCom had

92. See LTC, supra note 67, art. 35 .

93. See id. art. 4(2)

94. See id. 
been informed of Orange's intentions in this respect at the time that it granted the mobile telecommunication license. ${ }^{95}$

Yet another important subject in the European telecommunication sector relates to unbundling, the regulatory obligation of a former monopolist to "provide physical access for third parties to any technically feasible point of the copper local loop or sub-loop where the new entrant can co-locate and connect its own network equipment and facilities in order to deliver services to its customer, either in the local switch, concentrator or equivalent facility." ${ }^{, 96}$ As is the case with roaming, there is no explicit legal basis regarding unbundling in Switzerland, which is not a member of the European Union. Part of the discussion therefore turns on the question of whether the regulations applying to interconnection at the WTO and national levels constitute a sufficient basis for unbundling. ${ }^{97}$

\section{B. Electricity}

The Swiss market for electricity is currently dominated by several vertically integrated providers enjoying regional monopolies. This is reflected in electricity prices for the industry that are significantly higher than the Organisation for Economic Cooperation and Development ("OECD") average-the second highest in OECD after Japan-while prices for households are rather modest but still substantially above the OECD average. ${ }^{98}$

Strongly encouraged by the establishment, in 1999, of an internal electricity market in the European Union, and by deregulation measures in some E.U. member countries beyond what is required by E.U. legislation, the Swiss government started an electricity market reform in the late 1990s. A draft Federal Act on the Electricity Market ("Electricity Act") was presented by the federal government in June 1999. ${ }^{99}$ It should be adopted by the Parliament in 2000 and could enter into force in 2001 if there is no referendum challenge. According to this new act, the Swiss electricity market would be compatible with legislation governing the internal electricity market of the European Union.

The draft Electricity Act provides that the liberalization of the Swiss electricity market rests on the following main provisions:

(1) Regulated Third Party Access: Network operators have the duty to grant access to the grid on a non-discriminatory basis. The price

\footnotetext{
95. See Lawful Collaboration By Orange Communications SA with Swisscom within "National Roaming” Framework, ComCom Press Release of Oct. 8, 1999 (visited Nov. 30, 2000) $<\mathrm{http}: / /$ www.fedcomcom.ch/eng/press/mitteilung/58.html $>$.

96. Proposal for a Regulation of the European Parliament and of the Council on Unbundled Access to the Local Loop, COM(00)761 final, at art. 3(2).

97. See Rolf H. Weber, Entbündelung im Fernmeldemarkt, 4 SIC! 338 (2000). Technically, this can also be done through wireless local loop ("WLL") technology, which uses frequencies to give direct access to the customers of the provider. Thus, the monopoly of the holder of the local loop (or "last mile") is circumvented.

98. See ORganisation fOR ECON. COOP. AND DEV., OECD ECONOMIC SuRVEY 1998-99: SWITZERLAND 84 (1999).

99. See Feuille fédérale suisse [FF] 19997370 (Switz.).
} 
must be fixed according to the costs of an efficiently operated network. Network operators are entrusted with the drafting of a tariff scheme. If they do not come to an agreement, or if their agreement does not comply with the principles of cost orientation and transparency, the government may enact statutory rules for the pricing. ${ }^{100}$

(2) Formation of an independent arbitration commission: This new body, independent from the government, is responsible for the settlement of disputes concerning the access to the grid.

(3) Formation of a grid company: This company shall operate the transmission network (that is, the high-voltage system). It may not carry out activities relating to the generation or distribution of electricity.

(4) Unbundling of accounts: Integrated electricity companies shall keep separate accounts for their generation, transmission, and distribution activities. This should enable the authority to identify possible abuses, such as abnormally high tariffs or crosssubsidization.

The draft Electricity Act predicts the creation of conditions for effective competition in the electricity market within six years. However, a more rapid implementation of the Electricity Act would reduce the price disadvantage that Swiss industries and households currently bear compared to most neighbor countries. In other countries, such as Germany ${ }_{101}^{101}$ where the electricity market was fully liberalized in two years, ${ }^{102}$ some experts are predicting a shortening of the transition period of full market liberalization to less than six years. ${ }^{103}$

Liberalization is planned to begin with large power consumers. Indeed, in the first three years, only the 110 largest Swiss electricity users-accounting for twelve percent of total electricity consumption-would be given a choice of supplier, followed by smaller industrial users, and finally by households. A structural change of the sector is expected, as many of the 1200 small electricity producers will probably have to merge or go out of business, given the important potential for realizing economies of scale in the generation and distribution of electricity. ${ }^{104}$

Contrary to a previous proposal, the draft Electricity Act no longer calls for compensation payments to companies that invested in power plants in the past.

100. See Allen Fuchs, Öffnung des Strommarktes—Einige juristische Überlegungen, REVUE SUISSE DU DROIT DES AFFAIRES 52-67 (Special Issue 1999).

101. See Eurostat, Environment and Energy: Electricity prices for EU industry on 1 January 2000 and Electricity prices for EU households on 1 January 2000: downward trend, No. 5/00 (July 17, 2000); Communication from the Commission to the Council and the European Parliament, Recent Progress with Building the Internal Electricity Market, COM(00)297 final.

102. The two-year liberalization period resulted in a decrease in electricity prices for the industry by $25 \%$ to $35 \%$ and for households by $10 \%$.

103. See Organisation for ECON. COOP. AND DEV., OECD ECONOMIC SuRVEY 1999-2000: SWITZERLAND 40 (2000).

104. See id. 
Therefore, the energy producers are lobbying in favor of a new tax on nonrenewable energy sources in order to compensate for the "sunk costs." The debate on this issue could delay the reform of the electricity market. Regardless of the political discussion and prevailing legal confusion, market forces have already begun to work. In the group of large-end consumers, prices have fallen as much as thirty percent following conclusions of mid- and long-term delivery contracts between producers and these consumers. ${ }^{105}$

Given the absence so far of a legal framework accompanying the electricity market reform, the Competition Commission is playing an important role in the liberalization process. Its action is based largely on Article 7 of the Competition Act, which deals with the abuse of a dominant market position. ${ }^{106}$ The Competition Commission opened an investigation in July 1999, when a large regional electricity supplier was prevented from changing over to a cheaper foreign supplier. ${ }^{107}$ The regional operator, BKW FMB Energy Corporation, which was simultaneously an electricity provider and network operator, refused to transmit electricity power produced by any other enterprise throughout its network. ${ }^{108}$ The metal manufacturer Swissmetal was considering buying electric power from Laufenburg Energy Corporation through BKW's network. As a consequence of the intervention by the Competition Commission, BKW and Swissmetal agreed on a long-term contract at more favorable conditions for the plaintiff. $^{109}$ Therefore, the Competition Commission closed its investigation against BKW in February 2000. ${ }^{110}$ Since then, the Competition Commission has opened two investigations, as well as a preliminary investigation related to denial of third-party access. ${ }^{111}$

\section{NATIONAL COMPETITION LAW}

The aforementioned developments reveal how competition law can prepare the path to market liberalization. The most common and important problem appearing in newly, or soon to be, liberalized sectors-but also in the phase just preceding liberalization-is likely the abuse of dominance. In these sectors, the traditional monopolist is necessarily dominant and will remain so for many years. Furthermore, new competitors often rely on input supplied by the for-

105. See Philippe Gugler, The Role of Swiss Competition Policy in the Liberalisation Processes in Selected Markets (Jan. 2000) (unpublished manuscript, on file with author).

106. See Federal Act on Cartels and Other Competition Restraints of Oct. 6, 1995, RS 251 (Switz.).

107. See 1 COMMISSION DE LA CONCURRENCE, DROIT ET POLITIQUE DE LA CONCURRENCE 29-36

(2000) (visited Dec. 2, 2000) <http://www.wettbewerbskommission.ch/site/f/dpc/dpc.Par.0004.Pic0.pdf>.

108. See id.

109. See id.

110. See id.

111. See 2 COMmission de la conCURREnCE, Droit ET POLITIQUe De LA CONCURRENCE 15364 (2000) (visited Dec. 2, 2000) <http://www.wettbewerbskommission.ch/site/f/dpc/dpc.Par.0004.

Pic1.pdf>; ORganisation FOR ECON. COOP. AND DEV., OECD ANn. REP. ON COMPETITION POLICY 1999: SWITZERLAND 3 (1999). 
mer monopolist, such as access to local or universal networks, leading to disputes concerning refusals to deal and discrimination. Companies with a dominant position in a market risk violating Swiss competition law if they refuse access to facilities essential for competition. Typically, the facility is one that cannot practically or reasonably be duplicated, and access by the firm's competitors is feasible for the owner and necessary for competition. ${ }^{12}$

Competition issues in Switzerland are governed by the Federal Act on Cartels and Other Competition Restraints of 6 October 1995 (the "Cartel Act"). ${ }^{113}$ The Cartel Act is the result of a strong political willingness to maintain and improve the competitiveness of the Swiss economy. Indeed, a day after the Agreement on the European Economic Area was rejected by the Swiss people and the cantons, the government decided to create a working group with a mandate to propose a new legal framework in order to strengthen competition in Switzerland. Three years later, several laws were adopted to form the "revitalization program," whose main purpose was increasing competition within the country. This new competition policy is an important part of the "package" that includes the following laws: the Cartel Act, the Federal Law on the Elimination of Technical Obstacles to Trade, and the Federal Law on the Internal Market. ${ }^{114}$

\section{A. Application of Competition Rules}

Two categories of instruments are at the disposal of the Swiss Competition Commission in order to promote a competitive environment: (1) the competition enforcement measures and (2) the instruments of competition advocacy. The Competition Commission may enforce competition within the three basic pillars covering agreements, ${ }^{115}$ abuses of dominant positions (Article 7 of the Cartel Act) ${ }^{116}$ and concentrations. ${ }^{117}$

According to the Cartel Act, horizontal agreements that fix prices, the quantity or the range of products, or divide up markets geographically, are unlawful under the principle that that such agreements eliminate effective competition. ${ }^{118}$ All other agreements-horizontal as well as vertical-are unlawful if they significantly restrict competition and cannot be justified on grounds of economic efficiency. In addition, the Cartel Act indicates a non-exhaustive list of potential abuses of dominant positions that can be declared unlawful. Finally, the

112. This is the doctrine of "essential facilities." See generally KATHARINA SCHINDLER, WETTBEWERB IN NETZEN ALS PROBLEM DER KARTELLRECHLICHEN MiSSBRAUCHAUfSICHT-DiE

"ESSENTIAL FACILITY"-DOKTRIN IM AMERIKANISCHEN, EUROPÄISCHEN UND SCHWEIZERISCHEN KARTELLRECHT (1998).

113. See Federal Act on Cartels and Other Competition Restraints of Oct. 6, 1995, RS 251 (1996)

(Switz.).

114. See RS 251, RS 946.51, RS 943.02 (Switz.).

115. See RS 251, art. 5 (Switz.).

116. See id. art 7.

117. See id. arts. 9-10, 32-38; Swiss Federal Council's Ordinance on the Control of Concentrations of Undertakings, RS 251.4 (Switz.).

118. See RS 251, art. 7 (Switz.). 
Competition Commission may prohibit a concentration, or may authorize it subject to certain conditions or obligations, if the investigation reveals that the concentration creates or strengthens a dominant position liable to eliminate effective competition and does not correspondingly strengthen competition in some other market. In order to effectuate this control by the authority, the Cartel Act requires advance notice of planned mergers to the Competition Commission if the turnover of the enterprises concerned exceeds certain limits, ${ }^{119}$ or if the concentration relates to markets for which one of the participating undertakings has been the subject of a decision establishing a dominant position. ${ }^{120}$

Second, the Competition Commission may promote competition by offering advisory opinions to the Swiss federal and cantonal governments and lawmakers in the consultation procedures. ${ }^{121}$ Furthermore, it monitors the competition situation, and it may address recommendations to the authorities in order to promote effective competition, especially regarding the drafting and enforcement of laws. ${ }^{122}$

One of the shortcomings of the Cartel Act is the lack of power conferred on the Competition Commission to impose penalties on parties who are found to have restrained competition. To remedy this situation, a revision of the Cartel Act is underway. The major innovation of the revised law would be the introduction of direct penalties into the Cartel Act, as opposed to the current regime, where the Competition Commission may sanction cartels only if they do not respect a decision or the terms of an amicable settlement with the authority. $^{123}$

\section{B. Exemption from the Field of Application?}

In principle, Swiss competition law covers the entire economy; yet Article 3 of the Cartel Act provides several important exemptions. For example, competition law does not apply if other legal provisions do not allow competition in a market for certain goods or services. Such provisions take precedence over the provisions of the Cartel Act and include (1) provisions establishing an official market or price system and (2) provisions entrusting certain enterprises with the performance of public interest tasks, granting them special rights. In many cases, markets that are not yet liberalized or are in the process of liberalization fall under the exemption of Article 3 of the Cartel Act. In these situations, the

119. A notification is required if in the last accounting period prior to the concentration, the undertakings concerned reported joint turnover of at least 2 billion Swiss francs worldwide or turnover in Switzerland of at least 500 million Swiss francs. At least two of the undertakings concerned reported individual turnover in Switzerland of at least 100 million Swiss francs.

120. See RS 251, art. 9(4) (Switz.). This provision was applied to Swisscom after the Blue Window case, in which the Competition Commission considered that this company was holding a dominant position in the telecommunications market. See 2 COMMISSION DE LA CONCURRENCE, DROIT ET POLITIQUE DE LA CONCURRENCE 161 (1997) (visited Dec. 4, 2000) <http://www.wettbewerbskom mission.ch/site/g/praxis/rpw/recht_und_politik_des_wettbewerbs_1997_html>.

121. See RS 251, art. 46 (Switz.).

122. See id. art. 45

123. See id. art. 54 
Competition Commission can be active only through instruments of "competition advocacy." It should be emphasized, however, that the general view is that the above exemption applies only in a very restrictive way. ${ }^{124}$ This opinion is shared by the Competition Commission, which opened several investigations into the electricity market. ${ }^{125}$

Critics of liberalization argue that reforms affect distributional goals, such as universal service. This issue arises in the infrastructure of natural monopoly settings, where mandatory service obligations are funded by cross-subsidies. One of the most common justifications for protecting the incumbent firm from the entry of outside competitors is related to the existence of cross-subsidies in the tariff structure in order to attain some social goal, so that some services are provided at a loss, while others show high profit in order to compensate these losses. ${ }^{126}$ Thus, in the past it was argued that the introduction of competition for the provision of telecommunication services, such as telephone services, would harm universal services. This argument was based on the tendency for incumbent monopoly operators to grossly exaggerate the cost of universal service provision. $^{127}$

For governments, the first task of reform is often to identify and define the scope of the desired universality of the service. For example, in the European Union, the desired universality consists of the benefits that are essential for social ties or respecting fundamental liberties, which must be furnished to all at an affordable price and according to minimum standards of quality. ${ }^{128}$ In this area, the purpose of universal service legislation is twofold. First, it ensures its continued provision throughout the collectivity. Second, it avoids methods for its financing that would create barriers to entry for new competitors, thereby unduly subsidizing incumbent operators. The net cost of providing universal services must be shared between operators through a universal service fund. Governments that have liberalized telecommunication markets have continued to maintain universal service as a priority policy; however, countries have defined, delivered, and funded universal services in several ways with the onset of competition. In some countries, such as the United States, targeted subsidies funded by a special levy on customers have been provided to compensate for the high costs of providing service in specific areas or to specific income groups. $^{129}$ In other countries, such as Australia and the United Kingdom, the burden of universal services is shared among operators.

124. See ROGER ZÄCH, SCHWEIZERISCHES KARTELLRECHT 125 (1999).

125. See id.

126. See Organisation For ECON. CoOp. AND DeV., COMPETITION In TELECOMMUNiCATIONS 41 (1996).

127. See 1 Organisation FOR ECON. COOP. AND DEV., REPORT ON REgUlatory ReForm: SECTORAL STUDIES 40 (1997) [hereinafter OECD, SECTORAL STUDIES].

128. See 2 Organisation FOR ECON. COOPERATION AND DEV., REPORT ON REgUlatory REFORM: THEMATIC STUDIES 259 (1997).

129. See OECD, SECTORAL STUdIES, supra note 127. 
In Switzerland, the content of universal telecommunication services is legally defined in Article 16 of the 1997 federal law on telecommunications, the LTC:

The holder of a license to provide universal service shall provide the following technically state of the art services to meet demand in the area covered by the license:

a. public telephone service, i.e. transmission of speech in real time by means of telecommunication techniques, including transmission of data employing transfer rates compatible with the channels transmitting speech;

b. access to emergency call services;

c. sufficient public call boxes;

d. access to the Swiss directories of subscribers to the public telephone service;

e. a transcription service for people with impaired hearing, allowing them full access to telephone and emergency call services at comparable terms and conditions. ${ }^{130}$

In Switzerland, the former monopolist Swisscom has been granted an exclusive five-year license that will expire at the end of 2002. ${ }^{131}$ The special indemnification regime provided under the LTC does not apply during this period. ${ }^{132}$ In view of the above considerations, within the strict limits of Article 3 of the Cartel Act, it appears that universal services are, as a general rule, exempted from competition policy. The precise boundaries of this exemption are, however, rather difficult to define. It will be effective in the reserved areas where the legislature intended to grant exclusive or special rights. On the other hand, some provisions of the LTC impose special competition policy obligations on universal service suppliers. In particular, a universal service supplier must grant interconnection services to other providers even when it does not hold a dominant position. ${ }^{133}$ The Swiss lawmakers have set up an entire regime that gives the regulator the power to intervene should the universal service supplier take advantage of its position. ${ }^{134}$

\section{Mixed Rules and Situations}

The protection of effective competition is vital to the entire legal regime governing the liberalization of the Swiss telecommunications sector. It is part of the purpose clause of the law ${ }^{135}$ and appears explicitly in other legal provisions. ${ }^{136}$

\footnotetext{
130. LTC, supra note 67, art. 16.

131. See id. art. 66(1).

132. See id; see also id. art. 19(1):

If it is clear from the invitation to tender that, even with cost-effective management, it will be impossible for the investment required for the universal service in any given area to be written off within the usual period, the applicant who submits the

134. See, e.g., OTS, supra note 68, art. 21 (imposing quality criteria); OTS, art. 23 (mandating maximum rates).

135. See LTC, supra note 67, art. 1(2)(c).

136. The LTC provides:
} 
It bears repeating that interconnection regulations use the concept of dominant position to define the appropriate market share for the suppliers of these services. While the final determination rests in the hands of ComCom, the factual and legal analysis is performed in cooperation with the Competition Commission, which gives an opinion on the subject upon the regulator's request. ${ }^{137}$

Issues pertaining to competition were also present in the legislative process-for example, when the Swiss Parliament had to decide on the regime applicable to new procedures, such as those governing rights-of-way. In making this decision, the Parliament had to choose between public and private property and between a monopoly or a liberalized market. Other considerations included how many new lines to install and whether to have underground or overhead lines.

In its draft law presented to the Swiss Parliament, the Federal Council opted for absolute rights-of-way in favor of all telecommunication license holders, free of any indemnification and authorization procedures and applicable to all public and private properties. This was considered excessive by the Parliament, which eventually adopted a "softer" regime. ${ }^{138}$

Before its liberalization, the Swiss telecommunication market was subject to the monopoly of the state-owned Swiss Telecom PTT. The Federal Law on Electrical Installations granted that company an absolute right to use public property without need for authorization. ${ }^{139}$ When several new players arrive on the market, it is necessary to give a minimum amount of control to the owner(s) of such property. Moreover, owners of public property-such as the municipalities or, in Switzerland, the cantons that own pavements and roads-will not want operators to dig up their streets multiple times for the same purpose. Therefore, they will require these operators to coordinate their actions, and Swiss regulations provide for this coordination duty among operators. ${ }^{140}$

The "lines installed/lines to be installed" consideration is closely related to the "monopoly/liberalized market" consideration. Once the market is liberalized, former monopoly companies have an obvious competitive advantage over new players: They already own a very significant network, usually covering most of the country, while newcomers must build a network from scratch. Although interconnection is part of the solution, it cannot be the whole solution. Assuming that, as in Switzerland, the monopolist had been able to build its net-

\footnotetext{
The granting of a radiocommunications license must not eliminate or constitute a serious obstacle to effective competition unless an exception can be justified on grounds of economic efficiency. In case of doubt, the licensing authority shall conId. $\operatorname{art.}$ 23(4). sult the Competition Commission.

137. See id. art. 11(3).

138. See id. art. 35.

139. See Federal Law on Electrical Installations, art. 6, 4 RECUEIL SYSTÉMATIQUE DES LOIS ET ORDONNANCES 798 (1848-1947) (repealed).

140. See OTS, supra note 68 , art. 25 (relating to public policy concerns, such as protection of the environment, that are also present in other situations, like collocation where providers have to share part of their installations with other market participants).
} 
work free of charge without authorization, competition would be adversely affected because it would create additional costs (barriers) to market entrants if the lawmaker were to require authorization and the payment of an indemnity before the installation of new lines.

Competition would also be adversely affected if the regime favored a special category of new players, such as those using facilities in other markets, for example electricity companies and railways. Again, requirements relating to a strict authorization procedure and indemnification would disadvantage telecommunications companies that could not use electricity lines, ducts, or installations along railways to build their network.

The additional nuisance caused by overhead lines should also be taken into consideration and should result in a regime different from that applicable to underground lines. For example, one could envision a full authorization procedure with an indemnity to be paid to the owners of the properties crossed by overhead lines.

\section{$\mathrm{V}$}

\section{CONCLUSION}

In the process of liberalizing a market, competition law and sectoral regulations are closely related and often interact. Of course, one could argue that "the market"-in other words, effective competition-should be the sole determinant of providers' attitudes toward customers, in particular the services to be supplied and to whom and in what quantity. Then, a situation would develop where only competition authorities intervene, because the sectoral regulator would have disappeared from the scene. However, this situation ignores the fact that liberalized services, such as telecommunications and electricity, are part of public services, are essential elements of today's economies, and involve public interest aspects that cannot be addressed exclusively by competition. This is the case, for example, with universal services, which is the reason that Swiss current telecommunications regulations and the future Electricity Act contain specific provisions to guarantee basic services to the whole Swiss population, including people living in areas that it would not make commercial sense to reach and cover.

Switzerland also set up a regime where the regulator-ComCom-closely cooperates with the competition authority. Several provisions of the LTC provide that ComCom will seek advice from the competition authority. The idea behind this provision is to obtain an opinion from the Competition Commission, as a specialized authority, on concrete questions related to its field of competence. Typically, the Competition Commission will assist ComCom in an interconnection procedure by determining whether a telecommunications services provider holds a dominant position. In addition, the Competition Commission should keep its own competence of intervening in matters relating directly to the field of application of the Cartel Act, such as competition restraints and merger control. 
Situations exist where the application of regulatory measures has to be carefully watched from a competition standpoint. For example, although sharing should be encouraged as a means of providing efficient services to customers, notably in terms of coverage, there are risks involved. One such risk is of favoring anti-competitive conduct (agreements or creation of collective dominant positions). Collocation might also reduce the rate at which efficient individual networks develop, with new providers relying too heavily on the former monopolists' networks. Finally, the coordination duty imposed in connection with the use of public land by telecommunications providers might lead to some "parasitism" and violation of commercial and industrial secrecy, where competitors are made aware of the development plans of the other operators. 